\author{
J.-J. Sauvain · T. Vu Duc · M. Guillemin
}

\title{
Exposure to carcinogenic polycyclic aromatic compounds and health risk assessment for diesel-exhaust exposed workers
}

Received: 4 October 2002/ Accepted: 18 January 2003/Published online: 16 May 2003

(C) Springer-Verlag 2003

\begin{abstract}
Objectives: Workers' exposure to diesel exhaust in a bus depot, a truck repair workshop and an underground tunnel was determined by the measuring of elemental carbon (EC) and 15 carcinogenic polycyclic aromatic compounds (PACs) proposed by the US Department of Health and Human Services/National Toxicology Program (NTP). Based on these concentration data, the genotoxic PAC contribution to the dieselexhaust particle (DEP) lung-cancer risk was calculated. Method: Respirable particulate matter was collected during the summer and winter of 2001 (except for in the underground situation) and analysed by coulometry for EC and by GC-MS methods for PACs. The use of potency equivalence factors (PEFs) allowed the studied PAC concentrations to be expressed as benzo $[a]$ pyrene equivalents $\left(\mathrm{B}[a] \mathrm{P}_{\mathrm{eq}}\right)$. We then calculated the lung-cancer risk due to PACs and DEPs by multiplying the $\mathrm{B}[a] \mathrm{P}_{\mathrm{eq}}$ and $\mathrm{EC}$ concentrations by the corresponding unit risk factor. The ratio of these two risks values has been considered as an estimate of the genotoxic contribution to the DEP cancer risk. Results: For the bus depot and truck repair workshop, exposure to EC and PACs has been shown to increase by three to six times and ten times, respectively, during winter compared to summer. This increase has been attributed mainly to a decrease in ventilation during the cold. With the PEF approach, the $\mathrm{B}[a] \mathrm{P}_{\mathrm{eq}}$ concentration is five-times higher than if only benzo $[a]$ pyrene $(\mathrm{B}[a] \mathrm{P})$ is considered. Dibenzopyrenes contribute an important part to this increase. A simple calculation based on unit risk factors indicates that the studied PAC contribution to the total lung-cancer risk attributed to DEPs is in the range of $3-13 \%$. Conclusions: The 15 NTP PACs represent a small but non-negligible part of lung-cancer risk with regard to
\end{abstract}

J.-J. Sauvain $(\bowtie) \cdot$ T. Vu Duc $\cdot$ M. Guillemin Institut Universitaire Romand de Santé au Travail, Rue du Bugnon 19, 1005 Lausanne, Switzerland E-mail: Jean-Jacques.Sauvain@inst.hospvd.ch Fax: + 41-21-3147420 diesel exposure. From this point of view, the dibenzopyrene family are important compounds to be considered.

Keywords Polynuclear aromatic hydrocarbons . Elemental carbon - Diesel - Occupational exposure · Risk assessment

\section{Introduction}

Lung-cancer risk by occupation and socio-economic status has been shown to be high for workers who are exposed to inorganic dusts or fumes from fossil sources, even when the risk is adjusted for smoking (Bouchardy et al. 2002). For the trucking and transport industry, exposure to diesel exhaust has been put forward as a potential cause of such cancers. Epidemiological studies on working environments where diesel equipments are used show that the rate of lung cancer increases by $20-40 \%$ in generally exposed workers, and to a greater extent among workers with prolonged exposure (Cohen and Higgins 1995). Two recent meta-analyses of cohort and case-control studies in relation to occupational exposure to diesel exhaust and lung cancer indicate a very similar smoking-adjusted relative risk (RR) of between $1.33(95 \%$ confidence interval $(\mathrm{CI})=1.24-1.44$; Bhatia et al. 1998) and $1.47(95 \% \mathrm{CI}=1.29-1.67$; Lipsett and Campleman 1999). Other studies have provided some evidence that occupational exposure to diesel exhaust may be associated with lung cancer in bus garage workers $(\mathrm{RR}=1.34-2.43$; Cohen and Higgins 1995), for mechanics $(\mathrm{RR}=1.69 ; 95 \% \mathrm{CI}=0.92-3.09)$ and for long-haul and city truckers (respectively, $\mathrm{RR}=1.27 ; 95 \% \mathrm{CI}=0.83-1.93$ and $1.31 ; 95 \% \mathrm{CI}=0.81$ 2.11; Steenland et al. 1998).

Even if it is now accepted that diesel exhaust is a carcinogenic mixture, data on exposure levels are still the weak part in epidemiological risk assessment. Such lack of precise exposure data leads some authors to call into question the relationship between the level of reported lung-cancer risk and diesel-exhaust particles 
(DEPs) concentrations (Valberg and Watson 2000). The most comprehensive industrial-hygiene survey of diesel exposure in the trucking industry by job category has been conducted by Zaebst et al. (1991). Three main categories of diesel-exposed workers have been proposed (Valberg and Watson 2000): a low level (5$\left.100 \mu \mathrm{g} / \mathrm{m}^{3} \mathrm{DEP}\right)$, corresponding to truck drivers, dock workers, railroad workers (excluding shop workers and hostlers); a medium level (50-700 $\left.\mu \mathrm{g} / \mathrm{m}^{3} \mathrm{DEP}\right)$ for bus garage workers, railroad shop workers and hostlers, and finally, a high level $\left(500-2,000 \mu \mathrm{g} / \mathrm{m}^{3} \mathrm{DEP}\right)$ for underground miners.

As diesel exhaust is a complex mixture of particles and gases, it is necessary for compounds to be searched that can be considered to be exposure indicators. Several components of diesel exhaust have been evaluated for that purpose, and elemental carbon (EC) has been shown to be the most reliable overall measure of diesel-exhaust exposure Groves and Cain 2000). EC is a major component of diesel exhaust, contributing approximately $50 \%$ to $85 \%$ of diesel-particulate mass, depending on engine technology, motor load, fuel type and state of engine maintenance.

In terms of carcinogenicity/genotoxicity, the particulate phase with adsorbed chemical compounds is considered to be the most important fraction to be considered. Two paths are proposed to explain diesel exhaust-induced carcinogenesis (Nauss 1995):

1. A non-genotoxic mechanism, which is induced by particulate matter and which could be related to the EC concentration. Such mechanism may be predominant under high-level exposure conditions. The factors that may contribute to a tumour-promoting effect involve inflammation, cell proliferation, impairment of lung clearance and generation of reactive oxygen species (Scheepers and Bos 1992). Exposure measurements with EC as surrogate have been described in the literature for the trucking industry (Zaebst et al. 1991; Mattenklott et al. 2002; Groves and Cain 2000) and for underground tunnelling (Mattenklott et al. 2002).

2. A genotoxic mechanism, which is induced by carcinogenic/mutagenic organic substances that are adsorbed on DEPs. Such mechanism could be predominant at low-level exposure conditions. Polycyclic aromatic compounds (PACs) are thought to play a key role in such a process. In view of their biological potency, the most important PACs that have been detected in DEPs are:

- Polycyclic aromatic hydrocarbons (PAHs): indirect acting mutagenic and carcinogenic compounds, which need metabolic activation to electrophilic species to be biologically active. Typical concentrations are in the range of $180-800 \mathrm{ng} / \mathrm{m}^{3}$ total PAHs for dieselised mines, and $4-90 \mathrm{ng} / \mathrm{m}^{3}$ for benzo[a]pyrene $(\mathrm{B}[a] \mathrm{P})$ in mines and automobile repair shops (Bjørseth and Becher 1986).
- Nitro-PAH: direct acting mutagenic compounds with typical concentrations in workplace atmospheres being in the range of $0.012-1.2 \mathrm{ng} / \mathrm{m}^{3}$ for 1-nitropyrene (Scheepers et al. 1995).

- 3-nitrobenzanthrone: direct acting mutagenic compound with typical concentrations in diesel particle in the range of $0.6-6.6 \mu \mathrm{g} / \mathrm{g}$ (Enya et al. 1997).

Evidence to support the involvement of organic constituents of diesel particles in the carcinogenic process is given by the fact that PAH DNA-adducts for bus garage workers and mechanics exposed to diesel exhaust have been found to be significantly higher than for controls (Nielsen and Autrup 1994; Hemminki et al. 1994; Hou et al. 1995). Nitro-PAH adducts have also been detected in blood from bus garage workers and in urban and rural inhabitants, but the amount was comparable, which suggests that such compounds are general and widespread contaminants (Zwirner-Baier and Neumann 1999). Mineworkers are also exposed to such PACs, as determined in their urine by Seidel et al. (2002).

As mentioned by Verma et al. (1999), it may be prudent for one to include measurements of PAH in EC determination in order to assess occupational exposure to diesel exhaust. Due to the large number of possible active compounds found in diesel extracts, preferences among PACs have to be made. Although nitro-PAH concentration in DEPs (Campbell and Lee 1984) is reported to be of the same order as PAHs with more than four rings (Soontjens et al. 1997; Sauvain et al. 2001), these nitroarenes have not been regarded in this work. They have been shown to be less mutagenic than the PAHs as a group for human cells (Durant et al. 1996), and are less effective than PAHs in the induction of lung cancer when implanted into the lungs of rats (Grimmer et al. 1987). This last study indicated that most of the PAC carcinogenicity of diesel exhaust originates from compounds with four rings and more. Some questions have also been raised as to whether the nitropyrene family contributes significantly to the tumorigenic potency of diesel emissions (Nauss 1995). On the other hand, the US Department of Health and Human Services/National Toxicology Program (NTP) has proposed a list of 15 PACs of concern, which are classified as "reasonably anticipated to be human carcinogen" and which have been shown to be present in DEPs (Sauvain et al. 2001). We thus decided to focus on these 15 PACs in a first attempt to evaluate PAC exposure in diesel-polluted environments.

A useful approach for estimation of the health-risk posed by multi-component PAC exposure is based on the use of the individual compound's potency equivalence factor (PEF) relative to $\mathrm{B}[a] \mathrm{P}$. In a first step, a $\mathrm{B}[a] \mathrm{P}$ equivalent concentration $\left(\mathrm{B}[a] \mathrm{P}_{\mathrm{eq}}\right)$ is calculated by the multiplication of the individual PAC concentration 
Table 1 PEFs of the selected PAHs and PANHs relative to benzo[a]pyrene (Collins et al. 1998). Group $2 A$ classified as "probably carcinogenic to humans", Group $2 B$ classified as "possibly carcinogenic to humans"

\begin{tabular}{|c|c|c|c|}
\hline Name & Abbreviation & $\begin{array}{l}\text { IARC } \\
\text { classification }\end{array}$ & PEF \\
\hline $\begin{array}{l}\text { Reference } \\
\text { Benzo }[a] \text { pyrene }\end{array}$ & $\mathrm{B}[a] \mathrm{P}$ & $2 \mathrm{~A}$ & 1.0 \\
\hline $\begin{array}{l}\text { PAHs } \\
\text { Benz }[a] \text { anthracene } \\
\text { Benzo[}[b] \text { fluoranthene } \\
\text { Benzo[k]fluoranthene } \\
\text { Benzo[j]fluoranthene } \\
\text { Indeno[1,2,3- } c, d] \text { pyrene } \\
5-\text { Methyl chrysene } \\
\text { Dibenz }[a, h] \text { anthracene } \\
\text { Dibenzo[ }[a, e] \text { pyrene } \\
\text { Dibenzo[ } a, l] \text { pyrene } \\
\text { Dibenzo[ }[a, i] \text { pyrene } \\
\text { Dibenzo[ } a, h] \text { pyrene }\end{array}$ & $\begin{array}{l}\mathrm{B}[a] \mathrm{A} \\
\mathrm{B}[b] \mathrm{FT} \\
\mathrm{B}[k] \mathrm{FT} \\
\mathrm{B}[j] \mathrm{FT} \\
\mathrm{In}[c, d] \mathrm{P} \\
5-\mathrm{MeC} \\
\mathrm{DB}[a, h] \mathrm{A} \\
\mathrm{DB}[a, e] \mathrm{P} \\
\mathrm{DB}[a, l] \mathrm{P} \\
\mathrm{DB}[a, i] \mathrm{P} \\
\mathrm{DB}[a, h] \mathrm{P}\end{array}$ & $\begin{array}{l}2 \mathrm{~A} \\
2 \mathrm{~B} \\
2 \mathrm{~B} \\
2 \mathrm{~B} \\
2 \mathrm{~B} \\
2 \mathrm{~B} \\
2 \mathrm{~A} \\
2 \mathrm{~B} \\
2 \mathrm{~B} \\
2 \mathrm{~B} \\
2 \mathrm{~B}\end{array}$ & $\begin{array}{l}0.1 \\
0.1 \\
0.1 \\
0.1 \\
0.1 \\
1.0 \\
1.0^{\mathrm{a}} \\
1.0 \\
10.0 \\
10.0 \\
10.0\end{array}$ \\
\hline $\begin{array}{l}\text { PANHs } \\
\text { Dibenz }[a, h] \text { acridine } \\
\text { Dibenz }[a, j] \text { acridine } \\
\text { 7H-dibenzo }[c, g] \\
\text { carbazole }\end{array}$ & $\begin{array}{l}\mathrm{DB}[a, h] \mathrm{Acr} \\
\mathrm{DB}[a, j] \mathrm{Acr} \\
\mathrm{DB}[c, g] \mathrm{Car}\end{array}$ & $\begin{array}{l}2 \mathrm{~B} \\
2 \mathrm{~B} \\
2 \mathrm{~B}\end{array}$ & $\begin{array}{l}0.1 \\
0.1 \\
1.0\end{array}$ \\
\hline
\end{tabular}

${ }^{a}$ Value from Boström et al. (2002)

by its PEF. The carcinogenic potency of all considered PACs can then be estimated as the sum of each individual $\mathrm{B}[a] \mathrm{P}_{\mathrm{eq}}$. This approach is based on the assumption of additivity and that $\mathrm{B}[a] \mathrm{P}$ can be considered as a toxicological prototype for all other PACs. To date, the most comprehensive list of PEFs for different PACs is given by the Office of Environmental Health Hazard Assessment (OEHHA) of the California EPA (Collins et al. 1998). Table 1 shows the 15 NTP PACs that are considered in this study and shows that the most potent ones are mainly high-molecular-weight PAHs. Exposure data to such high-molecular-weight compounds is lacking for diesel-exhaust-contaminated working environments. Until now, the exposure measurements for PACs in the transport industry has mainly focussed on $\mathrm{B}[a] \mathrm{P}$ (Lindstedt and Sollenberg 1982; Waller et al. 1985; Ulfvarson et al. 1987; Limasset et al. 1993), or on rather low-molecular-weight PAHs (Fromme et al. 1998; Guillemin et al. 1992). Only the review of Cantrell and Watts (1997) mentioned concentration levels of two dibenzopyrenes in diesel-equipped underground mines.

The aim of this work is to provide more information on the workers' exposure to such carcinogenic PACs where diesel-exhaust exposure is expected to be medium-to-high, following Valberg and Watson's proposal (2000). We thus took samples from a bus depot, a truck repair workshop and an underground mine. For each of these work situations we determined the concentration in air of the 15 NTP PACs, and for EC, being considered as a surrogate to assess the DEP concentration. Based on these concentration data, we attempted to calculate the contribution of the analysed PACs to the total DEP lung-cancer risk. This calculation used the reported PAC PEFs and unit risk factors for $\mathrm{B}[a] \mathrm{P}$ and DEPs.

\section{Methods}

Description of workplaces and control strategies

Bus depot: the depot is located inside the urban centre of Lausanne City (Switzerland). It consists of a big hall (about 65,000 $\mathrm{m}^{3}$ ) in which buses (MAN SL 2000 and Van Hool models) are usually stationed overnight and are driven out at dawn during a period known as the "run out". Some vehicles return to the depot ("run in") during the day, depending on the traffic needs; the majority is back in the early-late evening. Activities such as bus maintenance (cleaning, tanking) and some small repairs are done in this depot. The diesel engines may be running within the depot during maintenance and also when the buses are started prior to leaving. There is a tendency for some drivers to start a vehicle and let it run to warm up the engine before run out. There are three distinct groups of employees who may be exposed to DEPs: cleaners, who spend their full working day within the depot, guards and engineering staff, who spend roughly half their time in the depot and, finally, the drivers who come just to warm up and drive the buses. Natural ventilation is maintained by the doors being kept open during all the working day, mainly during the warm season. A forced ventilation system is available, but is used mainly in the mornings during the first run out in winter time. The technical specification of this system corresponds to an air change rate of $2 \mathrm{~h}^{-1}$.

Truck repair workshop: the workplace studied is located in a suburb of Lausanne and consists of a big hall (about $50,000 \mathrm{~m}^{3}$ ) in which the main activities are truck/semi-trailer maintenance and repair (motors, tyres, electrical circuits), cleaning, and semi-trailers being prepared before they leave. Fork-lift trucks are in use to load and unload goods from lorries and to stock spare parts in the storehouse. Exposure to diesel exhaust is due to the run in-run out of the different vehicles, to displacement inside the hall, and when the repaired motors are tested. Exposed workers inside the workshop are mainly mechanics and, to a lesser extent, truck drivers. Flexible ducts attached to the tailpipe are available at some sites, mainly in the mechanics part. Otherwise, only natural ventilation is achieved, by personnel opening the doors that run along the full length of the workshop, and via some cupolas on the roof. In winter time, such ventilation seldom operates so as to prevent a low temperature in the hall. This lack of ventilation during winter is illustrated by the decrease in air changes rate, which falls from approximately $6 \mathrm{~h}^{-1}$ in summer to $2 \mathrm{~h}^{-1}$ in winter, based on the signal decay recorded by the direct reading PAS 2000 (see below, real-time measurements). These values were obtained by plotting the logarithm of a peak-signal decay vs time. A straight line is obtained, whose slope corresponds to the number of air changes.

Underground tunnel: the underground workplace that was sampled corresponds to the digging of a new tunnel in limestone with a low silica content. Conventional techniques, such as explosive attack followed by removal of the rubble by digger-filled dumpers, are used. The limestone face is then cleaned with a diesel-powered power pick and metallic structures are placed to consolidate the arch. Concrete is then sprayed onto the arch to secure the part that has been dug. Besides rock dust, workers are exposed to DEPs generated by the heavy-duty engines for almost the whole of the shift. Forced ventilation brings fresh air from the outside of the tunnel to the limestone face at a flow rate of $1.5-4 \mathrm{~m}^{3} / \mathrm{min}$. Some activities, such as extension of the ventilation tubing, imply a temporary stop of such a system.

\section{Sampling strategies}

Season has been shown to play an important role in diesel exposure of garage workers and mechanics (Waller et al. 1985; Zaebst et al. 1991). For the bus depot, two campaigns of 2 consecutive days were thus organised, in summer (18-19 of June and 16-17 of July 
2001; mean daily temperature $\left.17-23^{\circ} \mathrm{C}\right)$ and in winter (3-4 and $17-$ 18 of December 2001 ; mean daily temperature -6 to $15^{\circ} \mathrm{C}$ ). For the truck repair workshop, two campaigns of 2 consecutive days were carried out during the summer season (25-26 of June and 30-31 of July 2001; mean daily temperature $24-28^{\circ} \mathrm{C}$ ), whereas only one campaign was achieved during the winter season (9-10 of January 2002; mean daily temperature $11-18^{\circ} \mathrm{C}$ ). For the tunnelling site, no seasonal variation was expected; air was thus sampled during two summer campaigns (14 and 22 of August 2001). In this case, samples were taken during various activities: explosion and rubble removal by digger-filled dumpers, limestone face cleaning, and concrete sqraying to secure the arch.

All samples were collected for either 1 or 2 full working days (corresponding to one or two shifts, respectively), depending on the sampling device and the season.

Fixed sampling for the analysis of EC and PACs was performed at a height of between 1 and $1.5 \mathrm{~m}$. Personal sampling was not possible for PAC analysis, due to sensitivity limitations of the analytical method. Two sampling places were chosen during the first campaign in the bus depot and in the truck repair workshop so that the homogeneity of the PAC concentration could be assessed. As no significant differences were observed in the PAC concentrations, air sampling took place only in the vicinity of the main working place, during the subsequent campaigns, so that it was close to the workers' exposure.

\section{Real-time measurements}

A real-time aerosol monitor (miniRAM Model PDM-3, MIE, Billerica) that worked on the light-scattering principle was used to record the profile of particles smaller than $10 \mu \mathrm{m}$ during the workday. It samples air passively and was connected to a data logger (Eltek SQ-8, Eltek, Cambridge). In parallel, a real-time PAH sensor (PAS 2000, EcoChem, Überlingen), operating at a $222 \mathrm{~nm}$ wavelength and connected to a data logger (Hotbox BV 2, Elpro, Buch) was used. The PAS 2000 gives a signal which is a function of the amount of PAH adsorbed on particles; its response has also been shown to be proportional to the EC content of diesel particulates (Dahmann et al. 2002; Przybilla et al. 2002) and also correlates well with the bacterial genotoxicity of air-particle extracts (Wasserkort et al. 1998).

\section{Dust sampling and characterisation}

As air particles found in the selected working conditions are not only DEPs, the particle size distribution during each sampling campaign was determined by an Andersen cascade impactor (Model 1 ACFM, 9 stages, Andersen, Atlanta, Ga., USA) connected to a sampling pump operating at $28 \mathrm{l} / \mathrm{min}$. The concentrations of the nine fractions were determined by gravimetric measurements of the loaded filters on an analytical balance (Mettler AT-201, Mettler-Toledo, Greifensee; sensitivity $\pm 10 \mu \mathrm{g})$. All the filters were weighed after an equilibration period $(>24 \mathrm{~h})$ at ambient temperature and stable relative humidity $(50 \% \mathrm{RH}$, achieved with a saturated solution of $\mathrm{Ca}\left(\mathrm{NO}_{3}\right)_{2}$ in a glove box).

Total suspended particles and respirable dust concentrations $(<4 \mu \mathrm{m})$ were determined gravimetrically on the loaded filters by, respectively, high-volume pump and cyclone size selectors (Casella and PM4 type pump) as described below.

\section{EC sampling and analysis}

Organic carbon (OC) and EC concentrations were determined in the respirable fraction of the dust. Sampling was done with a size-selector cyclone (Casella, London) connected to a personal pump (Du Pont P2500, Du Pont, Wilmington, Del., USA) set at 1.9 1/min. The airflow was checked at least twice during the day with a calibrated flow meter (DryCal-DC lite, SKC, Eighty Four, Pa., USA). Only pre-cleaned quartz microfibre filters (Whatman QMA, Ø $37 \mathrm{~mm}, 2.2-\mu \mathrm{m}$ pore size) were used. Cleaning was achieved by plasma ashing (PlasmaPrep II, SPI, West Chester, Pa., USA) for 3 h at $450 \mathrm{~W}$ under $1 \mathrm{mbar}$ $\mathrm{O}_{2}$. The filters were weighed on a microbalance (Mettler M-3, Mettler-Toledo; sensitivity $\pm 1 \mu \mathrm{g}$ ), and samples were stored at $-20^{\circ} \mathrm{C}$ until required for analysis within the next 2 months.

OC-EC analysis was achieved on the whole filter by use of a thermal desorption system coupled to a coulometric titration device, described elsewhere (Perret et al. 1999). Briefly, after the filter has been introduced into the heating part of a coulomat (Ströhlein 720 $\mathrm{DR} / \mathrm{C}$, Düsseldorf, Germany), the system is purged and allowed to stabilise under a nitrogen atmosphere for $3 \mathrm{~min}$. The OC determination is performed by a fast temperature increase to $800^{\circ} \mathrm{C}$. This temperature is stepped until no change in electrolysis current is observed for $2 \mathrm{~min}$. The corresponding total electrolysis current corresponds to the $\mathrm{OC}$ content of the filter. In a third step that allows EC determination, the atmosphere is switched to an oxygen, the temperature is held at $800^{\circ} \mathrm{C}$ and the current zeroed. The EC content corresponds to the amount of electricity needed when no more counts are observed on the current meter for $2 \mathrm{~min}$. The samples from the tunnelling site were treated with $\mathrm{HCl}(200 \mu \mathrm{HCl}$ $1.5 \%$, evenly distributed on the filter and left for a minimum of $2 \mathrm{~h}$ at ambient temperature) because of the possible presence of interfering carbonate particles. Blank filters were analysed for each series, and quality control was achieved by re-analysis of a dieselloaded filter used during an inter-laboratory round-robin test within the framework of CEN/TC 137 (filter QF-708). The limit of detection (LOD) for EC with this method is in the range $2-5 \mu \mathrm{g} / \mathrm{m}^{3}$.

\section{PAC sampling and analysis}

A Gravikon PM-4 (GSM, Neuss-Norf) with a size-selector cyclone head was used for respirable-particle sampling. The flow was maintained at a constant $66.7 \mathrm{l} / \mathrm{min}$, and glass fibre filters (Macherey-Nagel MN 85/90, Ø $70 \mathrm{~mm}$, retained particles $>0.5 \mu \mathrm{m}$ ), which were cleaned as described for EC analysis, were used. As mentioned before, during one summer campaign, we used two high-volume pumps (Model 353, Sierra, Carmel Valley, Calif, USA; flow set at $230 \mathrm{l} / \mathrm{min}$ ) to assess the PAC homogeneity in the bus depot and truck repair workshop. The quartz filters that we used (Whatman QMA, $20 \times 25 \mathrm{~cm}$ ) were cleaned by ultrasonication in methanol (30 min), dichloromethane $(30 \mathrm{~min})$ and, finally, toluene $(30 \mathrm{~min})$. The cleaned filters were dried at $150^{\circ} \mathrm{C}$ and kept separately in aluminium foil until required for use. Samples were stored at $-20^{\circ} \mathrm{C}$ until required for analysis.

PAC analysis was achieved on the total filter by a method described by Sauvain et al. (2001). Briefly, after each sample has been spiked with deuterated internal standards, the filter is Soxhlet extracted with toluene for $24 \mathrm{~h}$. The extract is then concentrated, purified through a $10 \%$ deactivated SPE silica cartridge with dichloromethane:acetone 39:1. A semi-preparative HPLC fractionation on a silica column is further performed, and two fractions containing $\mathrm{PAH}$ and polycyclic aromatic nitrogen heterocyclic compounds (PANH), respectively, are obtained. A liquid-liquid partition is achieved on the PAH fraction and the PANH fraction is chromatographed on a polyvinylbenzene co-polymer column. The purified extracts are concentrated and finally injected on a Varian 3800 gas chromatograph coupled to a Varian 4D MS ion trap detector. On-column injection $(1 \mu \mathrm{l})$ was performed on a $30 \mathrm{~m} \times 0.25 \mathrm{~mm} \times 0.25 \mu \mathrm{m}$ BPX-50 column $(50 \%$ phenyl equivalent polysilphenylensiloxane, SGE, Weiterstadt). Certified diesel particulate matter SRM 1650 and field blanks were analysed with each sample series. No significant contamination was observed with the blank analysis.

\section{Assessment of PAC contribution to the total DEP lung-cancer risk}

One can assess the theoretical occupational lung-cancer risk due to the inhalation of DEPs or $\mathrm{B}[a] \mathrm{P}$ by multiplying the DEP or $\mathrm{B}[a] \mathrm{P}$ concentration by its corresponding unit risk factor. Such a 
Table 2 Unit risk factors used in this work, corrected for occupational exposure and for taking account of EC as surrogate in the case of DEP unit risk factors (see Method)

\begin{tabular}{lllr}
\hline Surrogate & References & Data source & $\begin{array}{l}\text { Unit risk factor } \\
\left(\mu \mathrm{g} / \mathrm{m}^{3}\right)^{-1 \mathrm{a}}\end{array}$ \\
\hline $\mathrm{EC}$ & $\begin{array}{c}\text { Stayner et al. (1998); } \\
\text { Scheepers and Bos (1992) } \\
\text { Stayner et al. (1998); } \\
\text { Scheepers and Bos (1992) }\end{array}$ & Rat exposure to DEPs & $2.8 \times 10^{-6}\left(0.01-54 \times 10^{-6}\right)$ \\
& Collins et al. (1991) & $\begin{array}{c}\text { Epidemiological study } \\
\text { (transport and railroad }\end{array}$ & $130 \times 10^{-6}\left(40-428 \times 10^{-6}\right)$ \\
$\mathrm{B}[\mathrm{a}] \mathrm{P}$ & Borkers, truck drivers) \\
& Boström et al. (2002) & $\begin{array}{c}\text { Inhalation and intratracheal } \\
\text { instillation in hamsters }\end{array}$ & $6.4 \times 10^{-4}\left(0.8-10 \times 10^{-4}\right)$ \\
Epidemiological study & $1.2 \times 10^{-2}\left(1.0-1.4 \times 10^{-2}\right)$ \\
\hline
\end{tabular}

${ }^{a}$ Median value of the data given in the references, with range in parentheses

calculation has been achieved for miners exposed to DEPs by Stayner et al. (1998). The unit risk is defined in our case as the risk corresponding to an occupational continuous exposure (assumed to be for 45 years, $8 \mathrm{~h}$ per day), to $1 \mu \mathrm{g} / \mathrm{m}^{3}$ of DEPs or $\mathrm{B}[a] \mathrm{P}$.

For carcinogenic compounds, a non-threshold dose-response curve is generally considered. In order for this dose-response curve to be extrapolated in these low concentrations, two kinds of models are used: statistical or mechanistic. The unit risks used in this study are mainly obtained from this last model, based on the so-called linearised multistage model. The unit risk corresponds to the slope of such an extrapolated line, when it is linear. Unit risks given in the literature are often representative of a lifetime exposure. Since we are interested in the occupational situation, and the occupational exposure is shorter than an entire lifetime, we must, of necessity, make an adjustment to this unit risk factor. We have thus applied a multiplicative factor of 0.21 to the lifetime unit risk value, as described by Stayner et al. (1998). Whereas EC represents only a small part of the illdefined DEPs, it has been retained as surrogate for DEPs in this study. This implies that the DEP unit risk factor has to be further corrected in order for this fact to be taken into account. One will thus calculate the EC-corrected DEP unit risk factor by dividing the DEP unit risk factor by a DEP/EC ratio of 2.5 . This ratio was used by Stayner et al. (1998) and is similar to the median value of 2.6 reported by Verma et al. (1999) for an underground mining environment. Table 2 summarises the unit risk factors obtained in this study, corrected when necessary to be representative for occupational exposure, and expressed for EC instead of DEPs. They are based mainly on values presented by Scheepers and Bos (1992), Stayner et al. (1998), Collins et al. (1991), and Boström et al. (2002).

As the carcinogenicity of DEPs is assumed to be due to a non-genotoxic pathway (particulate core) and a genotoxic pathway (adsorbed organics, mainly PACs), the total occupational lung-cancer risk, determined by the EC-corrected DEP unit risk factor times the EC concentration, can be estimated in a first approximation as the contribution of both pathways. Even if the interactions between these two pathways are difficult to assess, the main hypotheses are that each pathway contributes in an additive way to the total cancer risk, and that the PAC concentrations that are determined in the air result from diesel emissions only. For the genotoxic pathway, as a PAC mixture is involved, the potency equivalence factor (PEF) scheme is used to calculate the $\mathrm{B}[a] \mathrm{P}_{\mathrm{eq}}$ concentration, expressed in microgrammes per cubic metre. This $\mathrm{B}[a] \mathrm{P}_{\mathrm{eq}}$ concentration time the $\mathrm{B}[a] \mathrm{P}$ unit risk factor gives an estimation of the lung-cancer risk attributable to the PACs considered. One can thus evaluate the contribution of this genotoxic risk to the lung-cancer risk by dividing the PAC lung risk by the total lung risk based on EC measurement. In this calculation, we neglected the PAH contribution from the gas phase; the contribution of the volatile PAHs with two and three benzene rings has been shown to be biologically inactive when implanted into the lungs of rats (Grimmer et al. 1987).
Statistics

Some non-parametric tests, such as the Wilcoxon signed rank test and the Wilcoxon rank sum test, have been used to assess the difference between the selected working situations. These tests have been chosen due to the fact that the normality distribution of our small number of measurements cannot be confirmed.

\section{Results}

Direct-reading measurements and particle-size characteristics

Except for the tunnelling conditions, total dust given by the direct-reading miniRam did not provide useful information. This instrument is probably not sensitive enough to detect the low concentrations and rather small particle sizes in the bus depot and truck workshop. Figure 1 presents an example of the recorded signal from the real-time PAS instrument in the bus depot. A fairly good association is observed between this signal and the total numbers of vehicles leaving or entering the depot. Such a correlation is less marked for the truck workshop (data not shown), probably due to a response more influenced by local activities (displacement of a truck, air flow and so on). The mean value of the PAS signal is smaller in summer than in winter in the case of the bus depot (as shown in Fig. 1) and for the truck workshop. In summer, the PAS signal may return to a near-zero value, corresponding to a situation where PAC concentrations are low. In winter, such a situation seldom occurs; as soon as the first vehicles left or entered the bus depot or the mechanics' workshop, the PAS signal did not reach a baseline value anymore.

The use of an Andersen impactor allowed us to determine the size distribution during the different sampling campaigns. As no difference was observed between summer and winter distribution (Wilcoxon signed rank test, $P<0.05$ ), the contribution of each mean-size fraction to the total dust was calculated from these two sets of seasonal data and is presented in Fig. 2. The particle size distribution follows a log-normal law for the bus depot and the truck repair workshop. We verified this distribution by obtaining a straight line when the 

recorded for 2 consecutive days in a bus depot during the summer and winter. The number of bus run-ins (white bars) and run-outs (black bars) is indicated on the right-hand scale. Periods where the depot's doors were open and the ventilation system was on are symbolized by black horizontal line and double horizontal line, respectively. The daily mean PAS signal value is represented by a dotted line
Fig. 1 Typical PAS 2000 signal
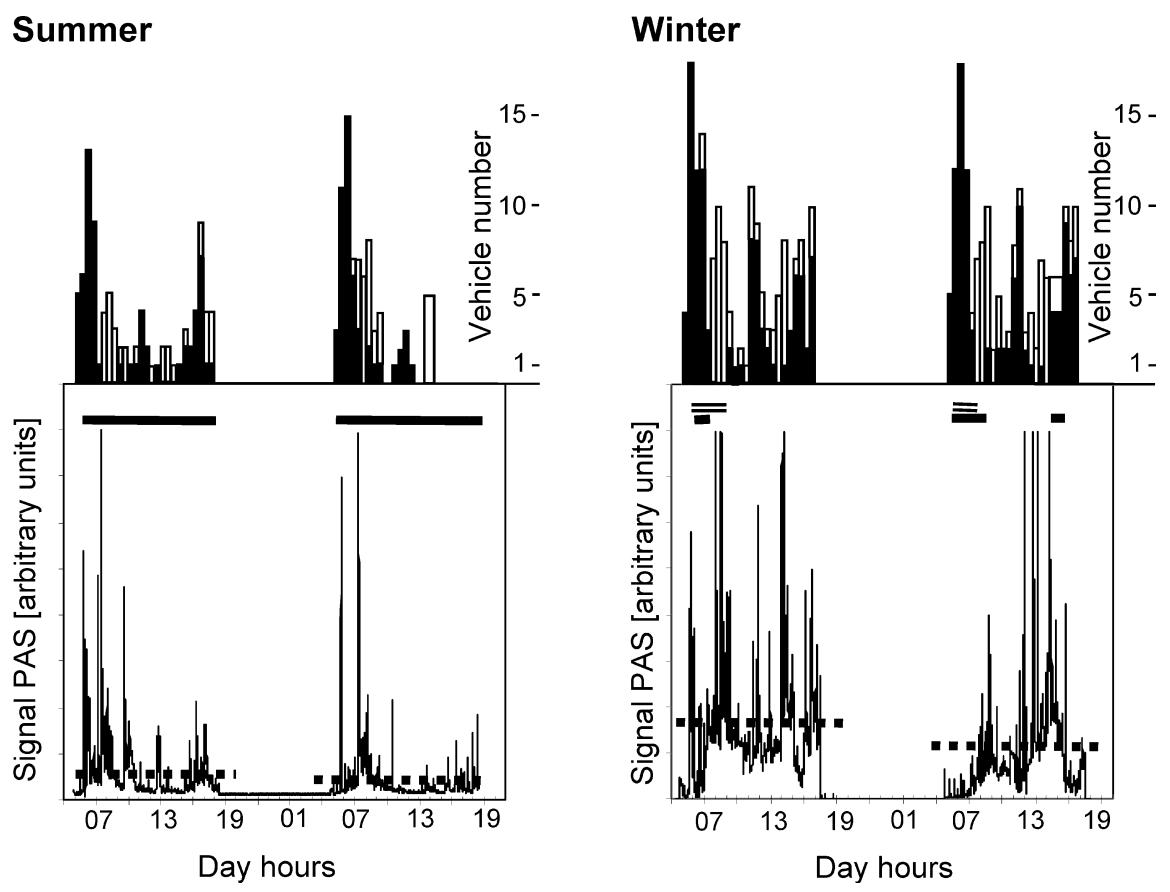

Fig. 2 Mean size distribution and standard deviation (vertical bars) of the sampled particle in a bus depot, truck repair workshop and during tunnelling

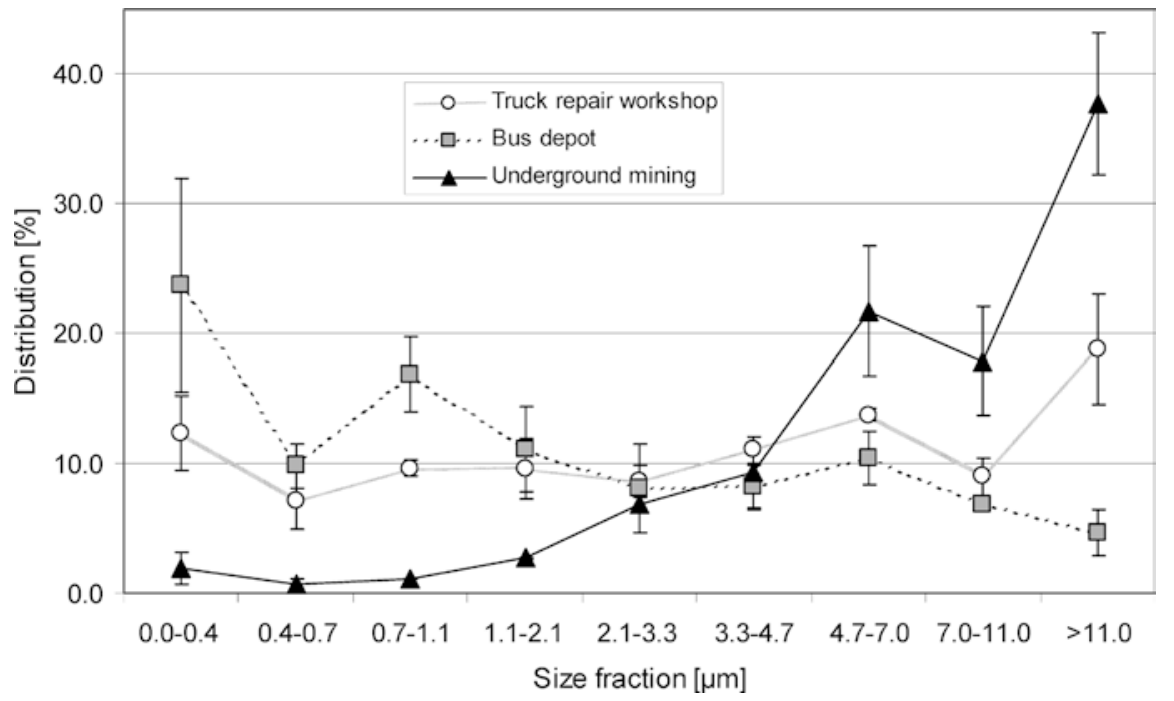

cumulative percent particulate of each impactor stage vs the corresponding cutoff were plotted on log-probability paper. The determination of the geometric mean size was based on the log-probability plot of the particle size. For the tunnelling conditions, where a bimodal distribution was observed, we determined the geometric mean size by following the procedure described by Knutson and Lioy (1989; Table 3).

Diesel aerosol is characterised by very small particles, with a mass median aerodynamic diameter of $0.2 \mu \mathrm{m}$ and $90 \%$ of the particles being less than $1 \mu \mathrm{m}$ (Watts 1995). Thus, a respirable-aerosol sampling device such as a cyclone collects all diesel and non-diesel aerosol particles (oil mist, pollen, cigarette smoke and so on) that fall into the respirable size range. As illustrated in Fig. 2 and
Table 3, each working condition differs, clearly based on the particle size distribution. Based on the Andersen impactor results, the bus depot is characterised by a high amount of respirable particles that reach approximately $75 \%$ of the total sampled mass, with a diesel contribution of around $40 \%$ (corresponding to particles smaller than $1.1 \mu \mathrm{m})$. The truck repair workshop presents a rather constant distribution of particle size, with diesel particles representing approximately $25 \%$ of the total dust mass. As expected, the coarse particulate matter $(>7 \mu \mathrm{m}$, probably mineral dust) is in the majority, in term of mass, in underground mine air compared with respirable $(\sim 20 \%)$ or diesel particulates $(\sim 4 \%)$.

The mean seasonal air concentrations for total suspended particles (TSPs), determined with the high-volume 
Table 3 Seasonal mean particle characteristics (Andersen impactor) and concentrations of the dust collected in the different working conditions with a high-volume pump (TSPs), or cyclone heads $(<4 \mu \mathrm{m})$

\begin{tabular}{|c|c|c|c|c|c|c|c|}
\hline \multirow[t]{2}{*}{ Season } & \multirow{2}{*}{$\begin{array}{l}\text { Working } \\
\text { environment }\end{array}$} & \multicolumn{4}{|c|}{ Particle characteristics } & \multicolumn{2}{|c|}{ Particle concentration } \\
\hline & & $n^{\mathrm{a}}$ & $\begin{array}{l}\text { Geometric mean } \\
\text { size }(\mu \mathrm{m})\end{array}$ & $\begin{array}{l}\text { Particles } \\
<4.7 \mu \mathrm{m}(\%)\end{array}$ & $\begin{array}{l}\text { Particles } \\
<1.1 \mu \mathrm{m}(\%)\end{array}$ & Cutoff & $\begin{array}{l}\text { Concentration } \\
\left(\mathrm{mg} / \mathrm{m}^{3}\right)\end{array}$ \\
\hline \multirow[t]{3}{*}{ Summer } & Bus depot & 2 & $1.7 \pm 4.4^{\mathrm{b}}$ & $72 \pm 5$ & $36 \pm 8$ & $\begin{array}{l}\text { TSP } \\
<4 \mu \mathrm{m}\end{array}$ & $\begin{array}{l}0.07 \pm 0.05 \\
0.04 \pm 0.02\end{array}$ \\
\hline & $\begin{array}{l}\text { Truck repair } \\
\text { workshop }\end{array}$ & 2 & $3.5 \pm 5.9$ & $52 \pm 3$ & $24 \pm 3$ & $\begin{array}{l}\text { TSP } \\
<4 \mu \mathrm{m}\end{array}$ & $\begin{array}{l}0.12 \pm 0.01 \\
0.06 \pm 0.01\end{array}$ \\
\hline & $\begin{array}{l}\text { Underground } \\
\text { mining }\end{array}$ & 2 & $7.7 \pm 2.5^{\mathrm{c}}$ & $23 \pm 5$ & $3.8 \pm 1.5$ & $<4 \mu \mathrm{m}$ & $2.21(0.82-7.04)^{\mathrm{d}}$ \\
\hline Winter & $\begin{array}{l}\text { Bus depot } \\
\text { Truck repair } \\
\text { workshop }\end{array}$ & $\begin{array}{l}2 \\
1\end{array}$ & $\begin{array}{l}1.3 \pm 4.6 \\
2.5 \pm 5.2\end{array}$ & $\begin{array}{l}77 \pm 2 \\
62\end{array}$ & $\begin{array}{l}44 \pm 8 \\
28\end{array}$ & $\begin{array}{l}<4 \mu \mathrm{m} \\
<4 \mu \mathrm{m}\end{array}$ & $\begin{array}{l}0.11 \pm 0.04 \\
0.23 \pm 0.03\end{array}$ \\
\hline
\end{tabular}

${ }^{\mathrm{a}}$ Number of sampling campaigns

${ }^{\mathrm{b}} \pm$ Mean geometric standard deviation

${ }^{\mathrm{c}}$ Not following a log-normal distribution
${ }^{\mathrm{d}}$ Mean value with minimum and maximum concentrations in parentheses

Table 4 OC and EC air concentration $\left(\mu \mathrm{g} / \mathrm{m}^{3}\right) \pm$ standard deviation for the three surveyed working environments, with their EC/TC ratio and some literature data for comparison

\begin{tabular}{|c|c|c|c|c|c|}
\hline Season & Working environment & $n^{\mathrm{a}}$ & $\mathrm{OC}$ & $\mathrm{EC}$ & $\mathrm{EC} / \mathrm{TC}(\%)$ \\
\hline Summer & $\begin{array}{l}\text { Bus depot } \\
\text { Truck repair workshop } \\
\text { Underground mining }\end{array}$ & $\begin{array}{l}2 \\
4 \\
5\end{array}$ & $\begin{array}{l}13 \pm 1 \\
23 \pm 4 \\
109 \pm 74\end{array}$ & $\begin{array}{l}5 \pm 1 \\
6 \pm 2 \\
79 \pm 15\end{array}$ & $\begin{array}{l}27.8 \pm 3.2 \\
20.7 \pm 3.7 \\
42.0 \pm 15\end{array}$ \\
\hline $\begin{array}{l}\text { Winter } \\
\text { Quality control }\left(\mu \mathrm{g} / \mathrm{cm}^{2}\right)\end{array}$ & $\begin{array}{l}\text { Bus depot } \\
\text { Truck repair workshop } \\
\text { Experimental } \\
\text { Mean CEN value }\end{array}$ & $\begin{array}{l}4 \\
3 \\
2\end{array}$ & $\begin{array}{l}33 \pm 15 \\
72 \pm 8 \\
26 \pm 3 \\
-\end{array}$ & $\begin{array}{l}19 \pm 10 \\
36 \pm 2 \\
49 \pm 3 \\
48 \pm 2\end{array}$ & $\begin{array}{l}36.5 \pm 3.0 \\
33.3 \pm 1.1 \\
- \\
-\end{array}$ \\
\hline
\end{tabular}

${ }^{\mathrm{a}}$ Total number of samples analysed

${ }^{\mathrm{b}}$ Mean with $95 \%$ confidence interval in parentheses

${ }^{\mathrm{c}}$ Without background correction

pump during the summer sampling campaign, and for the respirable fraction, determined with cyclone head, are presented in Table 3. The percentage of particles smaller than $4.7 \mu \mathrm{m}$ that were obtained with the Andersen impactor corresponds rather well with the concentration ratio of particles sampled with cyclone head to the TSPs.

An increase in the respirable-dust concentration between summer and winter for the two transport-industry environments (bus depot and truck repair workshop) is suggested by Table 3; it is significant (Wilcoxon rank sum test, $P<0.05$ ) only for the truck repair workshop.

\section{Measurement of OC and EC concentrations}

Table 4 presents the mean concentrations for OC and EC content of the different analysed samples. The total
${ }^{\mathrm{d}}$ Fifty percent of all data being smaller than first value and 95 percentile in parentheses

carbon (TC) corresponds to the sum of OC and EC concentrations. A statistically significant increase of EC and OC air concentration (Wilcoxon rank sum test, $P<0.05)$ is observed between summer and winter in the transport-industry environment. Such an increase between these two seasons is also statistically significant for the EC/TC ratio (Wilcoxon rank sum test, $P<0.05$ ).

\section{Measurement of PAC concentrations}

Table 5 presents the median concentrations determined for carcinogenic PACs adsorbed on the dust particles sampled in the three working environments. Only detected compounds are presented in this table and their sum outlined in the column " $\sum 15$ PACs". The air 


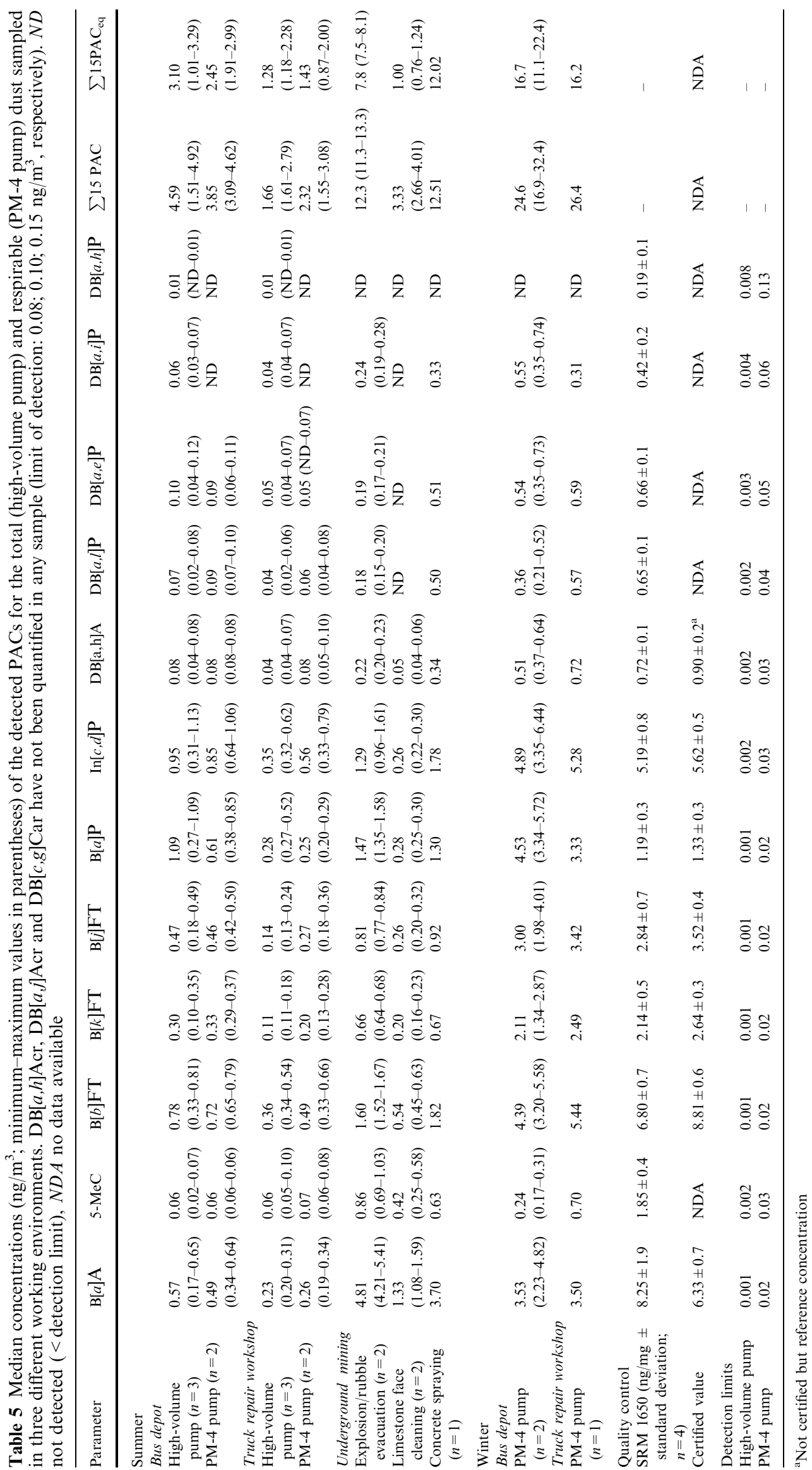



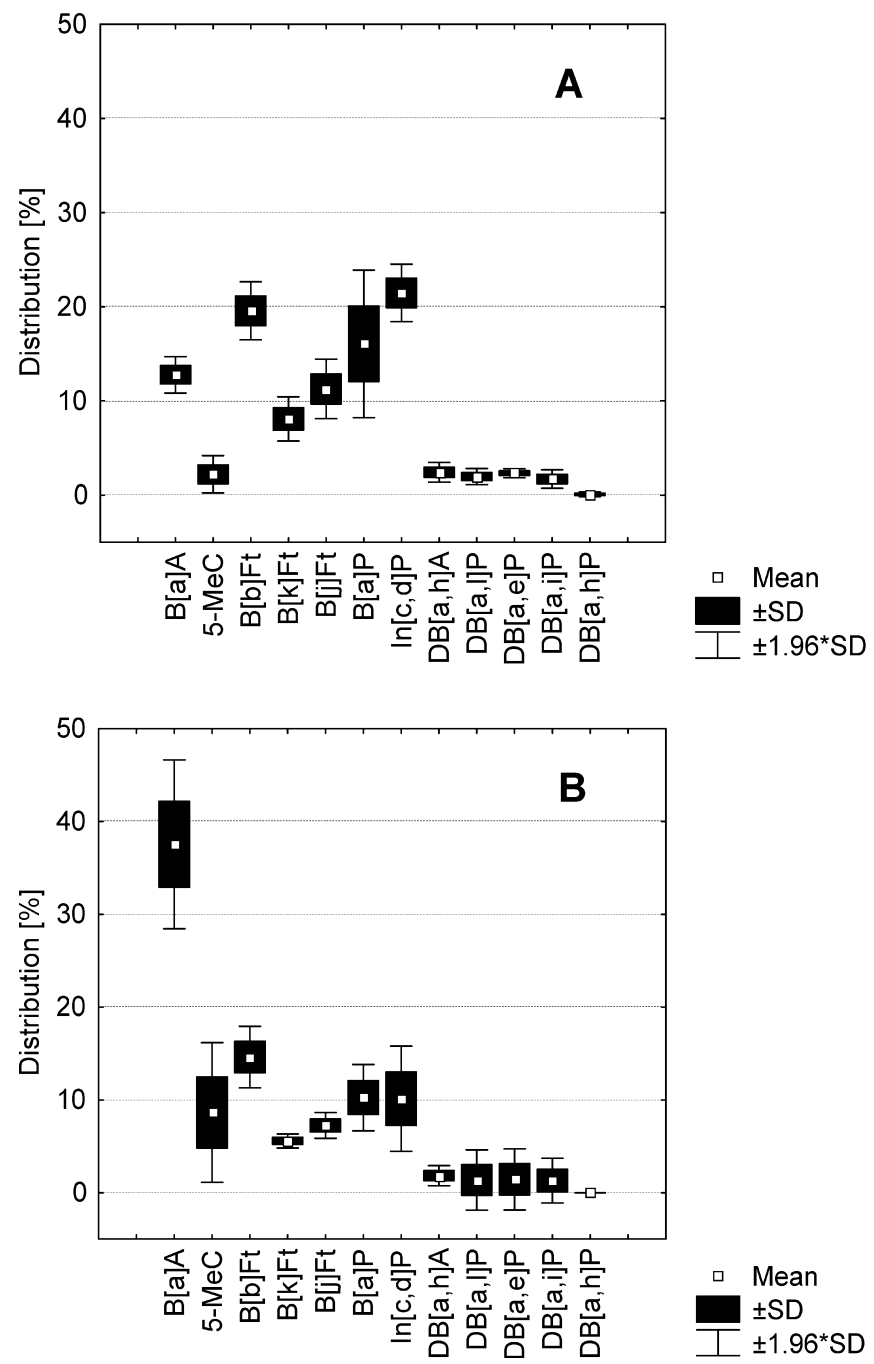
․ Mean $\mp \pm 1.96 * \mathrm{SD}$

Fig. 3A, B Mean PAC profile in the sampled air particles from A the transport branch (bus depot and truck repair workshop) and $\mathbf{B}$ the underground mining environment

volume that was sampled with the high-volume pump for 2 consecutive days ranged between 1,730 and $2,000 \mathrm{~m}^{3}$ and, for the PM4 pump, ranged between 87 and $100 \mathrm{~m}^{3}$. For the tunnelling conditions, the sampled volume was smaller, between 2.9 and $10.3 \mathrm{~m}^{3}$, depending on the mining activities. No high-volume sampling was achieved in this working environment, due to the high particle concentration in the air and the risk of filter clogging. Detection limits presented in Table 5 have been calculated based on the analyte mass that gives a mean signal $3 \sigma$ above the mean sample baseline signal ( $\sigma$ corresponds to the standard deviation of the baseline signal).

Based on these concentrations, the relative contribution of each compound to the $\sum 15$ PACs, expressed in percent, has also been calculated (Fig. 3). We carried out statistical tests on these data mainly to evaluate if differences exist in the PAC distribution profile for the three working environments that were surveyed. The Wilcoxon signed rank test indicated no difference
$(P<0.05)$ between the carcinogenic PAC profile in the bus depot and truck repair workshop, either according to season (summer or winter) or sampling-pump type (total suspended or respirable particles). All the distribution values corresponding to this working branch have thus been grouped and are presented in Fig. 3A. To test whether the individual PAC median value for the transport-industry distribution and the underground mine distribution (Fig. 3B) are different, we used the Wilcoxon rank sum test. A statistically significant difference $(P<0.05)$ was observed between these medians for all the detected PACs, except for dibenz $[a, h]-$ anthracene $(\mathrm{DB}[a, h] \mathrm{A})$, dibenzo[a,l]pyrene $(\mathrm{DB}[a, l] \mathrm{P})$, dibenzo[a,e]pyrene (DB $[a, e] \mathrm{P})$ and dibenzo[a,i]pyrene $(\mathrm{DB}[a, i] \mathrm{P})$. The percentages of benz $[a]$ anthracene $(\mathrm{B}[a] \mathrm{A})$ and 5-methyl chrysene $(5-\mathrm{MeC})$ are higher for the underground mine, whereas the percentages for the three benzofluoranthenes, $\mathrm{B}[a] \mathrm{P}$ and indeno $[1,2,3-$ $c, d]$ pyrene $(\operatorname{In}[c, d] \mathrm{P})$ are smaller than for the transport branch profile.

Assessment of PAC contribution to the total DEP lung-cancer risk

The PEF scheme, briefly described in the introduction, has been applied to the obtained PAC concentrations. One can calculate an individual $\mathrm{B}[a] \mathrm{P}_{\mathrm{eq}}$ by multiplying each compound concentration with the corresponding PEF value given in Table 1. Summation of all these $\mathrm{B}[a] \mathrm{P}_{\text {eq }}$ concentrations (Table 5, " $\sum 15 \mathrm{PAC}_{\text {eq }}$ ") gives an evaluation of the carcinogenic potency of all the quantified PACs and allows us to compare this with the one due to only $\mathrm{B}[a] \mathrm{P}$. Table 5 indicates that if this is taken into account, these biologically active PAHs increase the $\mathrm{B}[a] \mathrm{P}_{\mathrm{eq}}$ concentration by a mean factor of $5 \pm 2$.

A predicted total lung-cancer risk and PAC lungcancer risk among bus-depot workers and mechanics exposed to DEPs can be calculated by analogy to the procedure described by Stayner et al. (1998) and Tsai et al. (2001) and is presented in Table 6. The estimated contribution of the 15 NTP PACs to the total DEP lungcancer risk corresponds to the ratio PAC risk/DEP risk and is between $3 \%$ and $13 \%$. This value indicates that the PAC concentrations may contribute, in a relatively small but non-negligible part, to the total lung-cancer risk attributable to the diesel emissions.

\section{Discussion}

The signal of the PAS 2000 direct reading instrument has been shown to be rather well correlated with the number of run in-run outs and to the ventilation level in the bus depot and truck repair workshop. Such an instrument could be useful for the direct monitoring of the diesel exhaust level in these working conditions. For example, the mean signal recorded during summer 
Table 6 Predicted lung-cancer risk attributable to DEPs and the 15 NTP PACs, including an estimation of the genotoxic contribution to the DEP lung-cancer risk for the transport industry (bus depot and truck repair workshop)

\begin{tabular}{|c|c|c|c|c|c|c|c|c|}
\hline \multirow{2}{*}{\multicolumn{3}{|c|}{$\begin{array}{l}\text { Predicted DEP lung-cancer risk based } \\
\text { on measured EC concentration } \\
\text { Unit risk factor }\left[\left(\mu \mathrm{g} / \mathrm{m}^{3}\right)^{-1}\right]\end{array}$}} & \multirow{2}{*}{\multicolumn{3}{|c|}{$\begin{array}{l}\text { Predicted genotoxic lung } \\
\text { cancer risk based on } \mathrm{B}[a] \mathrm{P}_{\mathrm{eq}} \\
\text { Unit risk factor }\left[\left(\mu \mathrm{g} / \mathrm{m}^{3}\right)^{-1}\right]\end{array}$}} & \multirow{2}{*}{\multicolumn{3}{|c|}{ Genotoxic risk/DEP risk $(\%)$}} \\
\hline & & & & & & & & \\
\hline Rodent & \multicolumn{2}{|l|}{$2.8 \times 10^{-6}$} & Rodent & \multicolumn{2}{|l|}{$6.4 \times 10^{-4}$} & & & \\
\hline \multirow[t]{2}{*}{ Epidemiology } & $1.3 \times 10^{-4}$ & & Epidemiology & $1.2 \times 10^{-2}$ & & & & \\
\hline & Summer & Winter & & Summer & \multirow{2}{*}{$\begin{array}{l}\text { Winter } \\
1.6 \times 10^{-2}\end{array}$} & & Summer & Winter \\
\hline $\begin{array}{l}\text { Mean EC } \\
\text { concentration } \\
\left(\mu \mathrm{g} / \mathrm{m}^{3}\right)\end{array}$ & 6 & 28 & $\begin{array}{l}\text { Mean } B[a] P_{e q} \\
\text { concentration } \\
\left(\mu \mathrm{g} / \mathrm{m}^{3}\right)\end{array}$ & $2.1 \times 10^{-3}$ & & & & \\
\hline $\begin{array}{l}\text { DEP lung-cancer } \\
\text { risk }\end{array}$ & & & $\begin{array}{l}\text { Genotoxic lung-cancer } \\
\text { risk }\end{array}$ & & & & & \\
\hline Rodent & $1.7 \times 10^{-5}$ & $7.8 \times 10^{-5}$ & Rodent & $1.3 \times 10^{-6}$ & $1.0 \times 10^{-5}$ & Rodent & 7.6 & 12.8 \\
\hline Epidemiology & $7.8 \times 10^{-4}$ & $3.6 \times 10^{-3}$ & Epidemiology & $2.5 \times 10^{-5}$ & $1.9 \times 10^{-4}$ & Epidemiology & 3.2 & 5.3 \\
\hline
\end{tabular}

campaigns is clearly lower than that for winter campaigns. Such qualitative information is in accordance with the EC and PAC analysis results. If a quantitative result is needed, one difficulty with such a direct reading instrument is that a calibration has to be done. Such a calibration could be based on EC, as Dahmann et al. (2002) have shown, but an assessment of the robustness of such a technique has still to be done for occupational conditions.

This study suggests that the contribution to the total mass of particles with sizes $<1 \mu \mathrm{m}$, corresponding to the accumulation mode of diesel particles, is the highest for the bus-depot working environment. For the bus depot and truck repair workshop, approximately half of the respirable particle fraction may be attributable to diesel particles, in terms of mass. In terms of number of particles, this represents a huge number of small particles compared to the "large" ones. This fact may be relevant if the overload mechanism of lung macrophages is involved in the impairment process.

The EC concentrations determined in this study are below the TLV of $100 \mu \mathrm{g} / \mathrm{m}^{3}$ accepted by the Swiss National Insurance (Schweizerische Unfallversicherunganstalt (SUVA) 2001). For the transport industry, these concentrations correspond well with the range given by numerous authors for different jobs in this branch of economics (see Table 4). Particularly interesting is the fact that we found a clear increase in the EC concentration between the warm and cold seasons. The 4- to 6times increase observed in this work is very similar to the value of 6.2, indicated by Zaebst et al. (1991). This could indicate that diesel exposure increases during cold times, due to decreasing natural ventilation (door maintained closed). The door status has also been shown to influence the EC concentration in the air of railroad maintenance shops (Verma et al. 1999). These authors mention an EC concentration decrease of 1.5-2 times when doors are opened. The bus depot and truck repair workshop surveyed in this study are situated in the city or in the suburbs of Lausanne, respectively. A study conducted during 1995 and 1996 by the Swiss Forests and Environmental Agency on EC background values in different urban centres indicated for Lausanne City a mean yearly value of $5.4 \mu \mathrm{g} \mathrm{EC} / \mathrm{m}^{3}$ (range $1.0-9.6 \mu \mathrm{g}$ $\mathrm{EC} / \mathrm{m}^{3}$; Bundesamt für Umwelt, Wald und Landschaft (BUWAL) 1997). Such a concentration is very similar to the one measured during summer time in the bus depot and truck repair workshop. This could indicate that the EC air content during summer, when doors are largely opened for hall ventilation, is strongly influenced by the outdoor air. The ratio EC/TC is strongly influenced, e.g. by the motor regime, engine maintenance; a value of $>40 \%$ is commonly accepted for an occupational environment where diesel engines are working under heavy load, whereas a value $<20 \%$ corresponds to a light load (Groves and Cain 2000). In this study, all the samples are expected to derive from lightly loaded engines. The summer EC/TC ratio calculated for the transport industry situations is statistically lower than the one for winter time and is between $20 \%$ and $30 \%$. As engine load is expected to be identical all year long, this difference may indicate that more interfering organic compounds are present in the hall during summer. The source of such compounds has to be found in the outdoor air dust and could be pollen, road dust, rubber abrasion or cellulose particles. In winter, when doors are closed, this ratio increases, indicating a higher dieselrelated exposure. Very similar results are presented by Zaebst et al. (1991) for mechanics (see Table 4), confirming the potentially higher worker exposure to DEPs during winter for such jobs.

The PACs identified and quantified in this study involve exclusively PAHs. Whereas three polycyclic aromatic nitrogen heterocyclic compounds were considered, $\mathrm{DB}[a, j] \mathrm{Acr}$ was never detected and dibenz[a,h]acridine (DB $[a, h]$ Acr) and $7 \mathrm{H}$-dibenzo $[c, g]$ carbazole $(\mathrm{DB}[c, g]$ Car) could not be unambiguously identified in the different samples that were collected. The concentration range determined in this work corresponds to rather a low PAH occupational exposure, in comparison with, for example, aluminium production or foundries (International Programme on Chemical Safety (IPCS) 1998). The $\mathrm{B}[a] \mathrm{P}_{\mathrm{eq}}$ concentrations were always at least 100 times smaller than the Swiss TLV of $2,000 \mathrm{ng} / \mathrm{m}^{3}$ 
(SUVA 2001). Surprisingly, reported PAC concentrations are rather limited for occupational environments where diesel engines are in use and focus mainly on $\mathrm{B}[a] \mathrm{P}$. For this compound, concentration ranged from 0.1 to $14 \mathrm{ng} / \mathrm{m}^{3}$ in a London bus depot (Waller et al., 1985), 28-35 ng $/ \mathrm{m}^{3}$ for a Swedish repair shop (Bjørseth and Becher 1986) and approximately $4 \mathrm{ng} / \mathrm{m}^{3}$ in a Swedish industrial garage (Bjørseth and Becher 1986). Only one reference presents other PAH concentrations, in a Canadian underground mine, with $\mathrm{B}[a] \mathrm{A}$ ranging from 8.9 to $18.5 \mathrm{ng} / \mathrm{m}^{3}, \mathrm{~B}[\mathrm{k}] \mathrm{FT}$ from 2.6 to $5.4 \mathrm{ng} / \mathrm{m}^{3}$, $\mathrm{B}[a] \mathrm{P}$ from 1.2 to $1.9 \mathrm{ng} / \mathrm{m}^{3}, \mathrm{DB}[a, h] \mathrm{A}$ from 1.9 to $3.5 \mathrm{ng} / \mathrm{m}^{3}, \mathrm{DB}[a, e] \mathrm{P}$ from 4.6 to $8.4 \mathrm{ng} / \mathrm{m}^{3}$ and $\mathrm{DB}[a, i] \mathrm{P}$ from 0.9 to $1.9 \mathrm{ng} / \mathrm{m}^{3}$ (Cantrell and Watts 1997). Compared with these data, ours are approximately two to ten times lower for similar working environments.

The summer concentrations are very similar to the PAH concentrations determined for an urban air sample taken along a heavy-traffic road in Lausanne in October 1986 and analysed during this work (data not shown). This confirms that the summer indoor air is largely influenced by the contamination level of the outdoor air. Such an observation has already been reported for $\mathrm{B}[a] \mathrm{P}$ concentration in a London bus depot (Waller et al. 1985). The highest PAH exposure is observed during winter, when doors are closed, as for EC. Due to the lack of efficient ventilation systems or for economical reasons, the ventilation is not applied all day long, resulting in a PAH concentration increase by a factor of 5-10, compared to summer. A contribution from polluted urban air to this increase cannot be ruled out, due to the fact that a similar concentration increase has also been observed between summer and winter for urban PAH concentrations (BUWAL 1994). Concerning mining activities, lower PAH concentrations are observed during face cleaning, probably due to the involvement of a smaller number of diesel vehicles with small displacements and confined PAC emission further from the sampling point.

A significantly higher contribution of $\mathrm{B}[a] \mathrm{A}$ and 5$\mathrm{MeC}$ to the $15 \mathrm{PAC}$ profile is observed for the underground mining environment than for the transport industry. As light intensity is lower in tunnel mining than in other studied job situations, photo-oxidation could be a possible factor affecting this distribution. Indeed, $\mathrm{B}[a] \mathrm{A}$ presents the lowest photo-oxidation half-live, compared with $\mathrm{B}[a] \mathrm{P}$, benzo[b]fluoranthene $(\mathrm{B}[b] \mathrm{FT})$ or benzo[ $k]$ fluoranthene $(\mathrm{B}[k] \mathrm{FT})$ when adsorbed on soot or silica (IPCS 1998; Vu Duc and Huynh 1991). Differences in fuel composition or engine characteristics can also be involved (Yang et al. 1998).

This study clearly indicates that it is important for one to take into account PAHs other than $\mathrm{B}[a] \mathrm{P}$ alone when carcinogenic risk is being evaluated. If the PEFs of the 15 NTP PACs are considered, a 5-times higher $\mathrm{B}[a] \mathrm{P}_{\text {eq }}$ concentration is calculated. This increase can be considered as a lower factor, as other recognised carcinogenic PACs (nitro-PAHs, oxy-PACs, and so on) have not been considered in this study. Even if the concentrations of the most carcinogenic six-ring PAHs such as $\mathrm{DB}[a, l] \mathrm{P}, \mathrm{DB}[a, i] \mathrm{P}$ or $\mathrm{DB}[a, h] \mathrm{P}$ are about tentimes lower than $\mathrm{B}[a] \mathrm{P}$, this low concentration is compensated by their higher biological activity and leads to a significant increase in the expected mixture potency. It has to be mentioned that the dibenzopyrene concentrations indicated in this study may be overestimated, due to the presence of possible interfering isomers with the same molecular weight of 302 (naphthofluoranthenes and benzofluoranthenes, naphthopyrene and benzoperylenes). Such compounds have been detected in different matrices, and overlapping with isomers has been proved, based on UV and Shpolskii fluorescence (Wise et al. 1988). From a toxicological point of view, and for PAC risk assessment, these high-molecular-weight PAHs are thus important to be considered. This tendency for higher-molecular-weight PACs to be considered is illustrated by the fact that two recent papers propose, among others to take $\mathrm{DB}[a, l] \mathrm{P}$ as an indicator for environmental monitoring (Boström et al. 2002; Jacob and Seidel 2002).

Based on the simplistic risk calculation presented in Table 6, two points have to be stressed. First, the DEP lung-cancer risk obtained for the two transport workplaces studied is highest during winter time and reaches a magnitude that is similar to the significant risk level (not acceptable level), set at $10^{-3}$ (Tsai et al. 2001). This indicates that working conditions should be improved, mainly by the ventilation being increased during that time. Secondly, we estimate that the genotoxic risk of the 15 NTP PACs may contribute to a non-negligible part (3-13\%) of the total lung-cancer risk attributable to DEPs. These conclusions are valid only for the workplaces studied. Such a calculation contains a great part of uncertainty, and this contribution should be considered as being indicative for the magnitude. The difficulties with this exercise begin with the PEF definition and their determination. For example, the choice of $\mathrm{B}[a] \mathrm{P}$ as the reference compound to develop the PEF is presently questioned (Goldstein 2001). Due to the limited number of dose-response data on carcinogenicity, and depending on the exposure route (intratracheal administration, intrapulmonary injection, and so on), different PEFs can be obtained. For example, the PEF value used in this study for $\mathrm{DB}[a, l] \mathrm{P}$ is 10 , as given by Collins et al. (1998). This value may underestimate the relevance of this compound, because other authors claim a PEF value of 100 (Jacob and Seidel, 2002). The second main uncertainty is related to the unit risk factor calculated and presented in Table 2. These factors are based mainly on animals that have been exposed to high doses of DEPs. Extrapolation to low doses and the transferring of results from test animals to humans is not evident at all. This is illustrated by the fact that rodent-derived risk factors are approximately two orders of magnitude lower than epidemiologically derived risk factors. Another uncertainty is due to the fact that these risk factors have been corrected to take into account the reduced exposure time in occupational situations compared to lifetime. With 
regard to DEP risk, it has also been corrected to be expressed as a function of EC concentration. Finally, it has also to be remembered that the $\mathrm{B}[a] \mathrm{P}_{\text {eq }}$ concentrations used for this calculation represent an external exposure estimation of carcinogenic compounds and not the effective active concentration at the lung level.

Acknowledgements The authors acknowledge the various companies involved in this work for allowing them to sample in their buildings, and thank Dr. P. Schneuwly from Schweizerische Unfallversicherunganstalt, Lucerne, Switzerland for the loan of the PM-4 pump.

\section{References}

Bhatia R, Lopipero P, Smith AH (1998) Diesel exhaust exposure and lung cancer. Epidemiology 9:84-91

Bjørseth A, Becher G (1986) PAH in different workplace atmospheres. In: Bjørseth A, Becher G (eds) PAH in work atmosphere: occurrence and determination. CRC Press, Boca Raton, Florida, pp 117-139

Boström CE, Gerde P, Hanberg A, Jernström B, Johansson C, Kyrklund T, Rannung A, Törnqvist M, Victorin K, Westerholm R (2002) Cancer risk assessment, indicators, and guidelines for polycyclic aromatic hydrocarbons in the ambient air. Environ Health Perspect 110:451-488

Bouchardy C, Schüler G, Minder C, Hotz P, Bousquet A, Levi F, Fisch T, Torhorst J, Raymond L (2002) Cancer risk by occupation and socio-economic group among men - a study by The Association of Swiss Cancer Registries. Scand J Work Environ Health 28 Suppl 1:1-88

Bundesamt für Umwelt, Wald und Landschaft (BUWAL) (1994) VOC- und PAH-Immissions-messungen in der Schweiz (1991/ 1992). Umwelt-Materialien No. 10, BUWAL, Berne, Switzerland

Bundesamt für Umwelt, Wald und Landschaft (BUWAL) (1997) Russmessungen in der Aussenluft- Methodik und resultate. Umwelt-Materialien No. 80, BUWAL, Berne, Switzerland

Campbell RM, Lee ML (1984) Capillary column gas chromatographic determination of nitropolycyclic aromatic compounds in particulate extracts. Anal Chem 56:1026-1030

Cantrell BK, Watts WF (1997) Diesel exhaust aerosol: review of occupational exposure. Appl Occup Environ Hyg 12: 1019-1027

Cohen AJ, Higgins MWP (1995) Health effects of diesel exhaust: epidemiology. In: Health Effects Institute (eds) Diesel exhaust: a critical analysis of emissions, exposure and health effects. Health Effects Institute, Cambridge, Mass, USA, pp 251-292

Collins JF, Brown JP, Dawson SV, Marty MA (1991) Risk assessment for benzo[a]pyrene. Regul Toxicol Pharmacol 13:170-184

Collins JF, Brown JP, Alexeeff GV, Salmon AG (1998) Potency equivalency factors for some polycyclic aromatic hydrocarbons and polycyclic aromatic hydrocarbon derivatives. Regul Toxicol Pharmacol 28:45-54

Dahmann D, Matter U, Mosimann T (2002) Der photoelektrische Aerosolsensor (PAS), ein neues direkt anzeigendes Messgerät für Dieselmotoremissionen. Gefahrstoffe-Reinhaltung der Luft 62:7-11

Durant JL, Busby WF, Lafleur AL, Penman BW, Crespi CL (1996) Human cell mutagenicity of oxygenated, nitrated and unsubstituted polycyclic aromatic hydrocarbons associated with urban aerosols. Mutat Res 371:123-157

Enya T, Suzuki H, Watanabe T, Hirayama T, Hisamatsu Y (1997) 3-Nitrobenzanthrone, a powerful bacterial mutagen and suspected human carcinogen found in diesel exhaust and airborne particulates. Environ Sci Technol 31:2772-2776

Fromme H, Oddoy A, Piloty M, Krause M, Lahrz T (1998) Polycyclic aromatic hydrocarbons (PAH) and diesel engine emission (elemental carbon) inside a car and a subway train. Sci Total Environ 217:165-173
Goldstein LS (2001) To BaP or not to BaP? That is the question. Environ Health Perspect 109: A356-A357

Grimmer G, Brunne H, Deutsch-Wenzel R, Dettbarn G, Jacob J, Naujack KW, Mohr U, Ernst H (1987) Contribution of polycyclic aromatic hydrocarbons and nitro-derivatives to the carcinogenic impact of diesel engine exhaust condensate evaluated by implantation into the lungs of rats. Cancer Lett $37: 173-180$

Groves J, Cain JR (2000) A survey of exposure to diesel engine exhaust emissions in the workplace. Ann Occup Hyg 44:435447

Guillemin MP, Herrera H, Huynh CK, Droz PO, Vu Duc T (1992) Occupational exposure of truck drivers to dust and polynuclear aromatic hydrocarbons: a pilot study in Geneva, Switzerland. Int Arch Occup Environ Health 63:439-447

Hemminki K, Söderling J, Ericson P, Norbeck HE, Segerbäck D (1994) DNA adducts among personnel servicing and loading diesel vehicles. Carcinogenesis 15:767-769

Hou SM, Lambert B, Hemminki K (1995) Relationship between hprt mutant frequency, aromatic DNA adducts and genotypes for GSTM1 and NAT2 in bus maintenance workers. Carcinogenesis 16:1913-1917

International Programme on Chemical Safety (IPCS) (1998) Selected non-heterocyclic polycyclic aromatic hydrocarbons. Environmental Health Criteria 202, World Health Organization, Geneva, Switzerland

Jacob J, Seidel A (2002) Zur Problematik der Verwendung von Benzo $[a]$ pyren als Leitkompenente für das PAH-bedingte karzinogene Potenzial in Umweltmatrices. Gefahrstoffe-Reinhaltung der Luft 62:239-246

Knutson EO, Lioy PJ (1989) Measurement and presentation of aerosol size distributions. In: Hering SV (ed) Air sampling instruments. American Conference of Governmental Industrial Hygienists, Cincinnati, Ohio, USA, pp 59-72

Limasset JC, Diebold F, Hubert G (1993) Exposition des conducteurs de bus urbains aux polluants de la circulation automobile. Sci Total Environ 134:39-49

Lindstedt G, Sollenberg J (1982) Polycyclic aromatic hydrocarbons in the occupational environment - with special reference to benzo $[a]$ pyrene measurements in Swedish industry. Scand $\mathbf{J}$ Work Environ Health 8:1-19

Lipsett M, Campleman S (1999) Occupational exposure to diesel exhaust and lung cancer: a meta-analysis. Am J Public Health 89:1009-1017

Mattenklott M, Bagschik U, Chromy W, Dahmann D, Kieser D, Rietschel P, Schwalb J, Sinner KE, Stückrath M, Van Gelder R, Wilms V (2002) Dieselmotoremissionen am Arbeitplatz. Gefahrstoffe-Reinhaltung der Luft 62:13-23

Nauss KM (1995) Critical issues in assessing the carcinogenicity of diesel exhaust: a synthesis of current knowledge. In: Health Effects Institute (eds) Diesel exhaust: a critical analysis of emissions, exposure and health effects. Health Effects Institute, Cambridge, Mass, USA, pp 13-61

Nielsen S, Autrup H (1994) Diesel exhaust-related DNA adducts in garage workers. Clinic Chem 40:1456-1458

Perret V, Huynh CK, Droz PO, Vu Duc T, Guillemin M (1999) Assessment of occupational exposure to diesel fumes - parameter optimisation of the thermal coulometric measurement method for carbon. J Environ Monit 1:367-372

Przybilla K, Berkhahn W, Burtscher H, Dahmann D, Matter U, Rietschel P (2002) Monitoring diesel particulates in working areas with the photoelectric aerosol sensor. Gefahrstoffe-Reinhaltung der Luft 62:279-284

Sauvain JJ, Vu Duc T, Huynh CK (2001) Development of an analytical method for the simultaneous determination of 15 polycyclic aromatic hydrocarbons and polycyclic aromatic nitrogen heterocyclic compounds. Application to diesel particulates. Fresenius J Anal Chem 371:966-974

Scheepers PTJ, Bos RP (1992) Combustion of diesel fuel from a toxicological perspective. II. Toxicity. Int Arch Occup Environ Health 64:163-177 
Scheepers PTJ, Martens MHJ, Velders DD, Fijneman P, Van Kerkhoven M, Noordhoek J, Bos RP (1995) 1-Nitropyrene as a marker for the mutagenicity of diesel exhaust-derived particulate matter in workplace atmospheres. Environ Mol Mutagen 25:134-147

Schweizerische Unfallversicherunganstalt (SUVA) (2001) Valeurs limites d'exposition aux postes de travail, SUVA, Lucerne, Switzerland

Seidel A, Dahmann D, Krekeler H, Jacob J (2002) Biomonitoring of polycyclic aromatic compounds in the urine of mining workers occupationally exposed to diesel exhaust. Int J Hyg Environ Health 204:333-338

Soontjens CD, Holmberg K, Westerholm RN, Rafter JJ (1997) Characterisation of polycyclic aromatic compounds in diesel exhaust particulate extract responsible for aryl hydrocarbon receptor activity. Atmos Environ 31:219-225

Stayner L, Dankovic D, Smith R, Steenland K (1998) Predicted lung cancer risk among miners exposed to diesel exhaust particles. Am J Ind Med 34:207-219

Steenland K, Deddens J, Stayner L (1998) Diesel exhaust and lung cancer in the trucking industry: exposure-response analyses and risk assessment. Am J Ind Med 34:220-228

Tsai PJ, Shieh HY, Lee WJ, Lai SO (2001) Health-risk assessment for workers exposed to polycyclic aromatic hydrocarbons (PAHs) in a carbon black manufacturing industry. Sci Total Environ 278:137-150

Ulfvarson U, Alexandersson R, Aringer L, Svensson E, Hedenstierna G, Hogstedt C, Holmberg B, Rosén G, Sorsa M (1987) Effects of exposure to vehicle exhaust on health. Scand J Work Environ Health 13:505-512

Valberg PA, Watson AY (2000) Lack of concordance between reported lung-cancer risk levels and occupation-specific dieselexhaust exposure. Inhal Toxicol 12:199-208
Verma DK, Shaw L, Julian J, Smolynec K, Wood C, Shaw D (1999) A comparison of sampling and analytical methods for assessing occupational exposure to diesel exhaust in a railroad work environment. Appl Occup Environ Hyg 14:701-714

Vu Duc T, Huynh CK (1991) Photodecomposition rates of adsorbed PAH and mutagenic activity of irradiated synthetic mixture. In: Cooke M, Loenig K, Merrit J (eds) Polycyclic aromatic hydrocarbons: measurements, means and metabolism. Battelle Press, Columbus, Ohio, USA, pp 979-994

Waller RE, Hampton L, Lawther PJ (1985) A further study of air pollution in diesel bus garages. Br J Ind Med 42:824-830

Wasserkort R, Hartmann A, Widmer RM, Burtscher H (1998) Correlation between on-line PAH detection in airborne particles samples and their bacterial genotoxicity. Ecotoxicol Environ Saf 40:126-136

Watts WF (1995) Assessment of occupational exposure to diesel emissions. In: Health Effects Institute (eds) Diesel exhaust: a critical analysis of emissions, exposure and health effects. Health Effects Institute, Cambridge, Mass, USA, pp 109-123

Wise SA, Benner BA, Liu H, Byrd GD, Colmsjö A (1988) Separation and identification of polycyclic aromatic hydrocarbon isomers of molecular weight 302 in complex mixtures. Anal Chem 60:630-637

Yang HH, Lee WJ, Mi HH, Wong CH, Chen CB (1998) PAH emissions influenced by $\mathrm{Mn}$-based additive and turbocharging from a heavy-duty diesel engine. Environ Int 24:389-403

Zaebst DD, Clapp DE, Blade LM, Marlow DA, Steenland K, Hornung RW, Scheutzle D, Butler J (1991) Quantitative determination of trucking industry workers' exposure to diesel exhaust particles. Am Ind Hyg Assoc J 52:529-541

Zwirner-Baier I, Neumann HG (1999) Polycyclic nitroarenes (nitro-PAHs) as biomarkers of exposure to diesel exhaust. Mutat Res 441:135-144 